OPEN ACCESS

Edited by:

Aziz Ullah,

Kohat University of Science and Technology, Pakistan

Reviewed by:

Sergio Esposito,

University of Naples Federico II, Italy Joana Luísa Pereira, University of Aveiro, Portugal

*Correspondence: Xin Zhang

xin.zhang@uni-bremen.de

Specialty section:

This article was submitted to Environmental Toxicology,

a section of the journal

Frontiers in Environmental Science

Received: 08 September 2017 Accepted: 06 December 2017 Published: 18 December 2017

Citation:

Zhang X and Filser J (2017) Suitability of Contact-Free Oxygen Optical Microsensors for Measuring Respiration and Photosynthesis in Green Algae. Front. Environ. Sci. 5:91 doi: 10.3389/fenvs.2017.00091

\section{Suitability of Contact-Free Oxygen Optical Microsensors for Measuring Respiration and Photosynthesis in Green Algae}

\author{
Xin Zhang* and Juliane Filser \\ General and Theoretical Ecology, University of Bremen, UFT, Bremen, Germany
}

Oxygen optical microsensors are a sensitive method to monitor oxygen production and consumption in soils, sediments, and aquatic systems. They have been used widely to analyze the activity and metabolism of aerobic organisms, also in ecotoxicological tests. We aimed to assess the suitability of a contact-free device to measure cell respiration and photosynthesis for future applications in ecotoxicological tests. One of the most important advantages of this modified method is that respiration and photosynthesis of test organisms which are contaminated with test chemicals can be measured without contact between sensor and test medium. Therefore, it avoids sensor contamination. In an array of calibration tests with Chlorella vulgaris in green algae medium, algal cell activity was well-correlated with cell counts. Results clearly showed that, compared to $\mathrm{O}_{2}$ evolution rate, $\mathrm{O}_{2}$ assimilation rate measured by oxygen optical microsensors in a contact-free manner could better predict the algae cell counts. In a second test series we measured $\mathrm{O}_{2}$ assimilation rate in soil from a field experiment inoculated with different communities of terrestrial algae. No significant difference was observed when comparing measurements of their activity with microsensors to results obtained with the Warburg respiratory manometer. However, optical microsensors are much faster and more easily applied than the traditional manometer. Therefore, the developed method appears promising for application in ecotoxicological tests in the future.

Keywords: oxygen optical microsensor, ecotoxicology, respiration, photosynthesis, terrestrial algae, Chlorella vulgaris

\section{INTRODUCTION}

Algae are important in ecosystems as primary producers of all aquatic and some terrestrial food chains (Field et al., 1998; Krienitz, 2009). The increased interest in the role of green algae in terrestrial ecology (Buse et al., 2013; Schmidt et al., 2016) and ecotoxicology has emphasized the need for simple and objective methods of measuring their growth. Counting algae cells is the most popular method to estimate algae growth (Nyholm, 1990; Nyholm and Damgaard, 1990; Grote et al., 2005; Matzke et al., 2008), using either a counting chamber under the microscope or an automatic cell counter. Another option is to use chlorophyll concentration as an indirect measure, which employs organic solvent extraction (Jeffrey, 1974; Simon et al., 1997). All these methods have two disadvantages in ecotoxicological tests: (1) contact between equipment and test medium, and (2) some values of chlorophyll $a$ might be overestimated by the mixing of algae with litter from 
land plants (Tsujimura et al., 2000). In addition, it is difficult to compare chlorophyll $a$ extraction data between different studies, since ethanol, acetone, DMF (Dimethylformamide) and DMSO (Dimethyl sulfoxide) have been used as chlorophyll $a$ solvents, and the extraction efficiency differs between solvents (Castle et al., 2011; Lan et al., 2011). This is especially the case in soil samples which are more complex than aquatic samples because of the high variation of soil texture and organic matter. In soils, the method of counting algae cells using a microscope and fluorescence (Tchan, 1952) (Bowe, 2007) is controversial and time consuming. Some indirect methods which employ culture dilution and chlorophyll $a$ extraction (Hoffmann, 1989; Johansen, 1993) have their own limitations.

However, all these methods have a common disadvantage: contact between equipment and test medium. In ecotoxicological tests, especially with nanoparticles, it is difficult to remove the substances from the equipment. Over time, this gradually influences the characteristics of the equipment and affects the accuracy of measurements. Therefore, a contact-free, precise, reproducible and comparable method needs to be developed to improve algae quantification both in aquatic and terrestrial systems.

Oxygen microsensors are used widely in marine science to monitor the rate of oxygen production and consumption in sediments (Revsbech, 1989; Sweerts et al., 1990; Wetzel et al., 1995). They have been increasingly used in ecotoxicology to estimate respiratory activity by measuring dissolved oxygen in culture media (Klimant et al., 1995; Hynes et al., 2006; O’Mahony and Papkovsky, 2006). These microsensors are a sensitive method to analyze the activity and metabolism of aerobic organisms and have been suggested as a useful tool for toxicological assessment of chemical and biological samples (Porter et al., 1982; Kohra et al., 2002; Kühl, 2005). Such assessments provide rapid and sensitive responses to various stimuli and toxicological effects to test cells and organisms (O'Riordan et al., 2000; Kohra et al., 2002). However, those studies focused on the change of dissolved oxygen in the culture media and sediment due to the respiratory activity of test organisms and cells (Holst et al., 1995). Again, the contamination of the sensor by toxicants is not avoided and will gradually influence the accuracy and sensitivity of the test.

A new type of optical electrodes, so-called optical microsensors, was introduced into microbial research by Klimant et al. (1995), and successfully applied to invertebrates, plant tissues, and aquatic organisms (Gansert et al., 2001; Warkentin et al., 2007; Ast et al., 2012). In order to design an assessment with high accuracy for ecotoxicological studies, contact-free equipment is the key. With this in mind, we assessed the suitability of a method which can monitor oxygen concentrations both in aquatic and terrestrial systems without direct contact. In this study, oxygen optical microsensors were used to monitor both respiratory and photosynthesis activity of green algae (Chlorella vulgaris) in algae medium by measuring oxygen concentration in the headspace of a closed vial. The same method was applied in a soil system to measure respiration of different soil algae. The aims of our work were: (1) to find out if algae cell counts correlate with cell activity (photosynthesis and respiration) which were measured by the oxygen optical microsensor in the headspace of closed vials; (2) to investigate which parameter $\left(\mathrm{O}_{2}\right.$ assimilation or evolution rate) is more reliable for predicting cell concentration; (3) to compare the measurements of soil substrate induced respiration between this new contact-free method and the traditional Warburg manometer.

\section{MATERIALS AND METHODS}

We used two different setups for testing the method. The first series of experiments was done with a culture of $C$. vulgaris in liquid medium, aiming for calibrating cell counts with the sensor signal when measuring either oxygen evolution or assimilation rate. In the second setup we measured oxygen assimilation in soil samples from a field experiment with different treatments and compared the results with those obtained by a Warburg manometer.

\section{Algal Strain and Growth Conditions}

An axenic strain of $C$. vulgaris was supplied by the Culture Collection of Algae (SAG) at Göttingen University, Germany. The permanent cultures were kept on agar in glass tubes under day light at room temperature. Prior to starting the experiments, algae stock cultures were taken from the permanent culture into Nunc EASY $75 \mathrm{~cm}^{2}$ cell culture flasks (from VWR, Hannover, Germany) under sterile conditions (Clean Air CA/REV four, Labexchange, Germany) to synchronize growth for 11 days. Every 4 days, the cultures were transferred and checked for cell counts to keep them in exponential growth. For this, 750 $\mu \mathrm{L}$ of "old" culture was transferred with sterile pipettes into a new flask of fresh medium, to achieve an initial concentration of about a factor 100 smaller than in the old culture. The cultures kept in the exponential growth phase were maintained on a shaker (IKA ${ }^{\circledR}$ MTS $2 / 4$ digital, Staufen, Germany) with $150 \mathrm{rpm}$ in a climate chamber (neoLab-Thermostatschrank ET 618-4/135, Germany) at $22 \pm 1^{\circ} \mathrm{C}$ with a light-dark cycle of $14: 10 \mathrm{~h}$. Four days before the tests the required amount of algae to reach an initial concentration of $2.5 \times 10^{4}$ cells $/ \mathrm{mL}$ was taken from the synchronized cultures and added to $50 \mathrm{~mL}$ green algae medium (GAM; see Table A1). This pre-culture was established to render an algae concentration suitable for the inoculation of test cultures. Cultures were incubated on a shaker at continuous illumination with 6600 lux (Sylvania Luxline plus F 15w/865 Daylight deluxe, Australia).

\section{Oxygen Optical Microsensor and CASY ${ }^{\circledR}$ Automatic Cell Counter}

The oxygen optical microsensors OXR50 (optical isolation) were purchased from PyroScience (Aachen, Germany). The principle of the measurement is based on the quenching of the redflash dye luminescence caused by collision between oxygen molecules and the red-flash dye immobilized on the sensor tip. The red-flash dye is excitable with red light at a wavelength of 610-630 nm and shows an oxygen-dependent luminescence in the near infrared (NIR, 760-790 nm) (PyroScience Manual). Details and technical specifications provided by the manufacturer (Table A2) are given in the Supplementary Material. Two-point 
calibrations were performed with four sensors connected to the device. Pure nitrogen gas and ambient air with known humidity (55\%) were set as 0 and $100 \%$ air saturation. These two-point calibration procedures were repeated prior to each experiment. In order to exclude ambient oxygen, sample vials are well-sealed with rubber lids. The oxygen optical microsensor produces a change of luminescence in response to the depletion of oxygen in the vial due to the respiration of test organisms (Kühl, 2005). When the organisms' respiratory activity increases, the oxygen concentration decreases. The principle is the same when photosynthesis is used to measure cell activity. The sensor signals are recorded automatically by a computer. The profiles of the sensor luminescence signals directly illustrate the oxygen assimilation rate.

Algae were counted with an automatic cell counter (CASY ${ }^{\circledR}$ Model TTC, Roche Diagnostics GmbH, Mannheim, Germany) which is widely used to record healthy cells in ecotoxicological tests. It obtains the exact number of algae cells which are suspended in a special solvent (CASY ${ }^{\circledR}$ ton) inside the capillary. When the healthy cells go through the measuring pore, an enlarged level of electrical resistance is detected at once. Within a selected diameter range (to distinguish the target cells from other larger or smaller particles), dead cells and dust which do not act as an electrical barrier are not recorded.

\section{$\mathrm{O}_{2}$ Evolution and Assimilation Tests}

Photosynthesis and respiration of $C$. vulgaris at different concentrations were measured by microsensors. Calibrations between $\mathrm{O}_{2}$ evolution/assimilation rate and $C$. vulgaris cell counts were done. Experiments were performed in a large water bath with a constant temperature at $22^{\circ} \mathrm{C}\left( \pm 0.1^{\circ} \mathrm{C}\right)$ in an air-conditioned room with a constant temperature of $22^{\circ} \mathrm{C}$. $30 \mathrm{~mL}$ glass flasks closed with air-tight rubber lids (silicone septum, $3.2 \mathrm{~mm}$ VWR, Germany) were used. This allow the microsensor syringe needles to penetrate (Figure 1). The required concentrations of $C$. vulgaris (Figures 2,3) were diluted with green algae medium in $50 \mathrm{~mL}$ Erlenmeyer flasks and then $10 \mathrm{~mL}$ test samples were transferred from the Erlenmeyer flasks into $30 \mathrm{~mL}$ glass flasks (the exact space volume is $31 \mathrm{~mL}$ ) for the microsensor measurement. The volume ratio of head space and suspension is 21:10.

To assess the relationship between algae cell concentrations and $\mathrm{O}_{2}$ evolution and assimilation rates we used the counts recorded by the algae cell counter CASY ${ }^{\circledR}$. Each concentration was replicated four times. A temperature control flask was used in parallel to each test. Measurements were run immediately after adjusting the position of the sensor tip $1 \mathrm{~cm}$ above the liquid surface. The respiration tests were run in the dark, and for the photosynthesis tests ambient light was provided by three white (OSRAML 36W/865, Germany) and two warm color fluorescent bulbs (OSRAML 36W/11, Germany) with $182 \mu \mathrm{mol} \mathrm{m} \mathrm{m}^{-2} \mathrm{~s}^{-1}$ continuous illumination. Luminescence readings in each sensor were taken automatically every $15 \mathrm{~s}$ over the course of $30 \mathrm{~min}$. The calibration curve was obtained within $12 \mathrm{~h}$. Three independent repeats of both tests were run in winter, spring and summer.

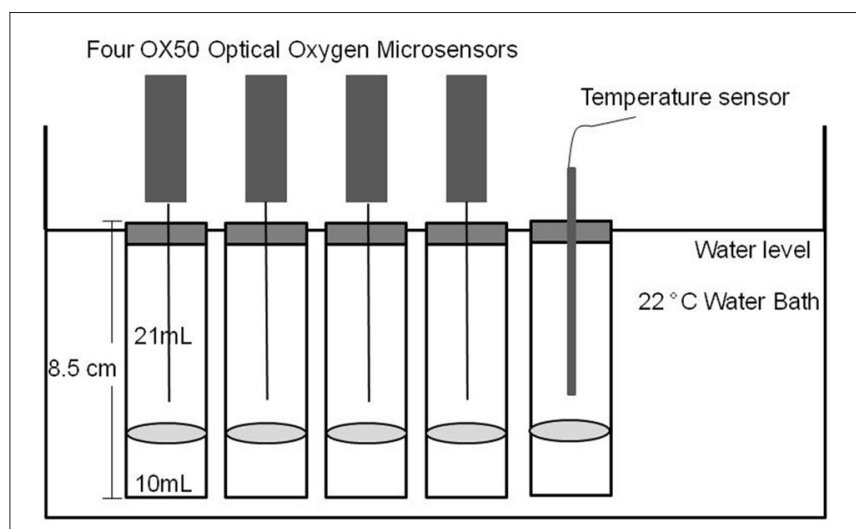

FIGURE 1 | Setup of the optical oxygen microsensors in the aquatic experiments.

\section{Comparison with Warburg Manometer}

In order to test the accuracy and efficiency of the method we compared $\mathrm{O}_{2}$ assimilation rates measured by oxygen optical microsensors with a traditional manometer. It was designed by Otto Heinrich Warburg (Warburg, 1956; Drobnik, 1960) and has been used widely in plant physiology and soil microbiology (Syrett, 1951; Kleinzeller, 1965; Schaefer et al., 2005). The Warburg manometer is an analytical instrument for measuring the pressure of gases and vapors from biochemical reactions It was originally used to study respiration and uptake of gaseous $\mathrm{O}_{2}$ and the production of $\mathrm{CO}_{2}$ by various cells and tissues (Warburg, 1956; Kohler, 1973).

In this study, measurements were performed with soils from a sandy research site at Bremen University $\left(\right.$ ReviTec $^{\circledR}$; see Table 1 for soil properties). Samples were taken from three different existing experimental plots (Kf, Wild, Mix) at the ReviTec ${ }^{\circledR}$ site which had been established by Prof. Hartmut Koehler and PhD student Thomas Buse. Field plots had been inoculated with the cultures in April 2011, and samples were taken in April 2012. Sample Control was pure washed river sand. Sample Kf was taken from plots inoculated with laboratory cultured Klebsormidium flaccidium as representative filamentous terrestrial algae. Sample Wild had been inoculated with a community of wild algae consisting of different single cell and filamentous algae species from the ReviTec ${ }^{\circledR}$ site, and sample Mix was from a plot inoculated with cultures of $K$. flaccidium and the wild population.

Substrate-induced respiration (SIR) rate, a method for calculating soil microbial biomass (Anderson and Domsch, 1978; Sparling et al., 1981; Kaiser et al., 1992; Ananyeva et al., 2011) was measured by both Warburg and optical microsensors. Soil from the four different samples ( $10 \mathrm{~g}$ each) was separately mixed with $0.5 \mathrm{~mL} 10 \%$ glucose and distilled water to reach $50 \%$ water holding capacity. Alkaline absorption $(\mathrm{KOH})$ was used in Warburg bottles to absorb $\mathrm{CO}_{2}$. The volume of $\mathrm{CO}_{2}$ was recorded every $30 \mathrm{~min}$ for $6 \mathrm{~h}$ at $22^{\circ} \mathrm{C}$.

Sample preparation for the oxygen optical microsensors measurement was similar to the procedure described for the aquatic algae cultures. Instead of algae medium, the prepared soil 


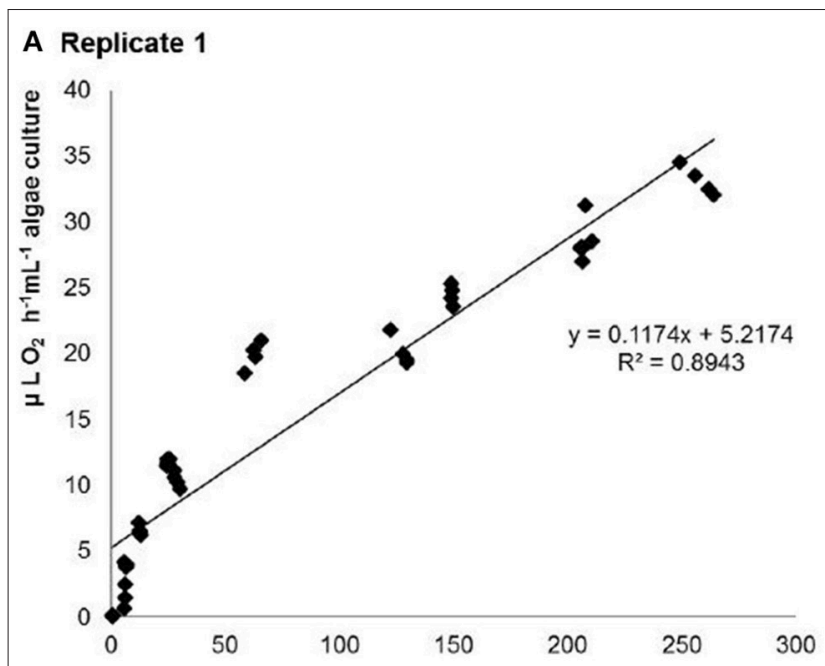

\section{B Replicate 2}

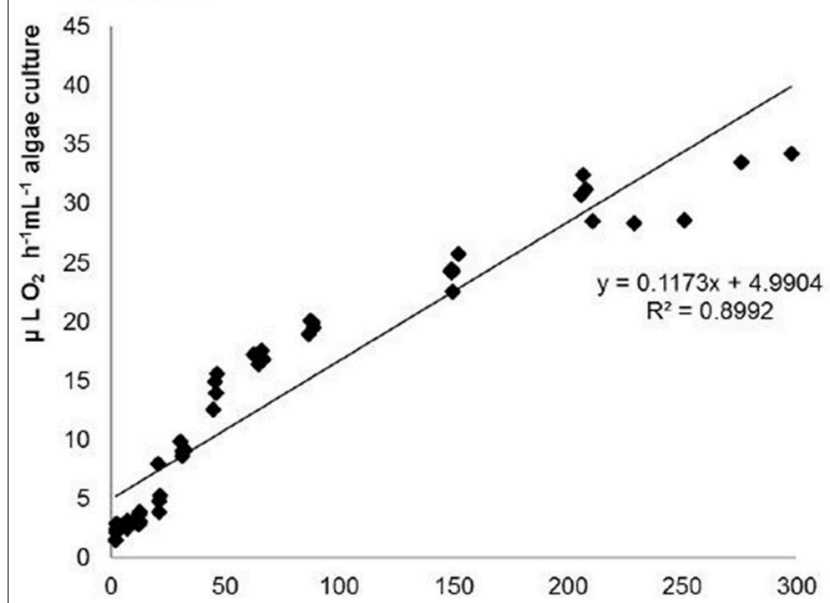

\section{Replicate 3}

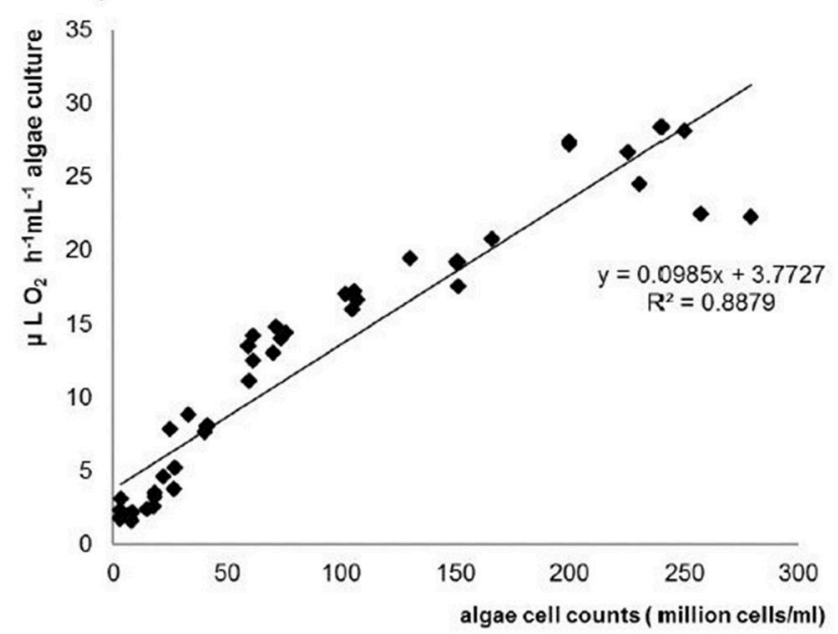

FIGURE 2 | Relationship between light-induced $\mathrm{O}_{2}$ evolution rate and C. vulgaris cell counts estimated by $\mathrm{CASY}{ }^{\circledR}$ cell counter with $10 \mathrm{~mL}$ test samples in three repeats. (A-C) replicate 1-3.

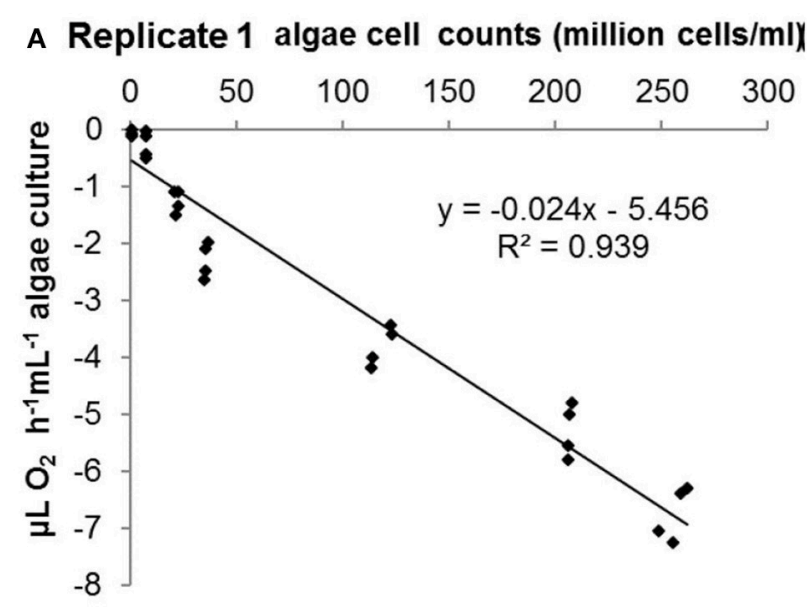

B Replicate 2

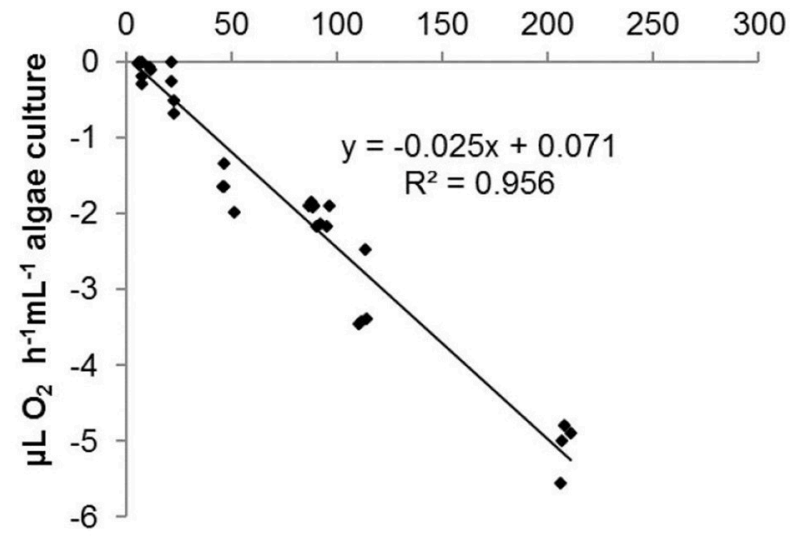

C Replicate 3

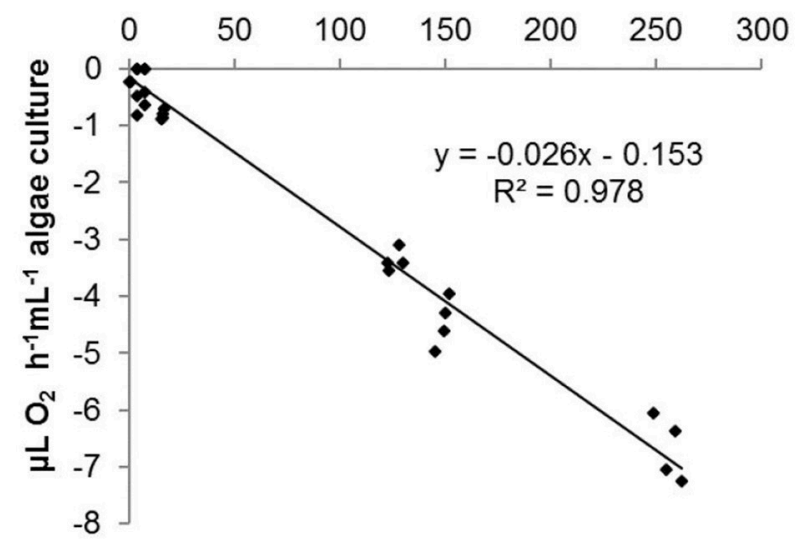

FIGURE 3 | Relationship between $\mathrm{O}_{2}$ assimilation rate and $\mathrm{C}$. vulgaris cell number estimated by CASY ${ }^{\circledR}$ cell counter with $10 \mathrm{~mL}$ test samples in three repeats. (A-C) Replicate 1-3.

samples ( $10 \mathrm{~g}$ soil mixed with $0.5 \mathrm{~mL} 10 \%$ glucose and distilled water) were transferred into $30 \mathrm{~mL}$ glass flasks and closed with air tight rubber lids. The experiments were performed in a water 
TABLE 1 | Soil Properties of ReviTec ${ }^{\circledR}$ soil using in soil respiration tests.

\begin{tabular}{ccccccc}
\hline $\begin{array}{c}\text { Sand \% } \\
(\mathbf{w} / \mathbf{w})\end{array}$ & $\begin{array}{c}\text { Silt \% } \\
(\mathbf{w} / \mathbf{w})\end{array}$ & $\begin{array}{c}\text { Clay \% } \\
(\mathbf{w} / \mathbf{w})\end{array}$ & $\mathbf{p H}$ & $\begin{array}{c}\mathrm{C}_{\text {org }} \\
(\%)\end{array}$ & $\begin{array}{c}\boldsymbol{N}_{\text {total }} \\
(\mathbf{m g} / \mathbf{k g})\end{array}$ & $\begin{array}{c}{ }^{*} \mathbf{W H C} \\
(\mathbf{m l} / \mathbf{k g})\end{array}$ \\
\hline 99.63 & 0.37 & 0 & 6.25 & 0.04 & 0 & 205 \\
\hline
\end{tabular}

*Water holding capacity.

bath with a constant temperature of $22^{\circ} \mathrm{C}$ and measurements were run immediately after adjusting the position of the sensor tip $1 \mathrm{~cm}$ above the soil. In the end, microbial biomass carbon of the samples was calculated based on the maximum initial respiratory response at $22^{\circ} \mathrm{C}$ according to Kaiser et al. (1992). The following equation was used: $\mathrm{x}=30 \mathrm{y}$, where $\mathrm{x}$ is total microbial carbon biomass and $y$ is maximum initial rate of $\mathrm{CO}_{2}$ respiration $\left(\mathrm{mL} \mathrm{CO}_{2} \mathrm{~kg}^{-1}\right.$ soil h $\left.\mathrm{h}^{-1}\right)$ or $\mathrm{O}_{2}$ consumption $\left(\mathrm{mL} \mathrm{O}_{2}\right.$ $\mathrm{kg}^{-1}$ soil h $\left.\mathrm{h}^{-1}\right)$.

\section{Statistical Analyses}

Statistical analyses were performed with SPSS 17.0. Regression analyses and Pearson correlations were conducted to analyze the data on oxygen evolution and assimilation rate. For comparison between the Warburg manometer and optical microsensor in differently treated field soils, a GLM was applied to analyse the main effects and interactions between treatment and method (hypothesizing no difference between the methods and no interactions between both factors). Then a one-way ANOVA was run, followed by a post-hoc Dunnett-test to compare each treatment to the respective control of two methods.

\section{RESULTS}

\section{$\mathrm{O}_{2}$ Evolution and Assimilation Rate Calibration Tests}

This experiment was undertaken to create calibration curves between C. vulgaris cell counts and oxygen evolution/assimilation rate in algae medium during the process of algae photosynthesis/respiration. Pearson correlations $(p<0.001)$ between algae cell counts and $\mathrm{O}_{2}$ evolution/ assimilation over a wide cell number range were observed in all experiments.

No significant difference was observed between the three repeated tests. Regression analyses indicated linear relationships between algae cell counts and both $\mathrm{O}_{2}$ evolution $\left(r^{2}=0.894\right.$, $r^{2}=0.899, r^{2}=0.888$ in three repeated tests; see Figure 2 and Table 2) and assimilation $\left(r^{2}=0.939, r^{2}=0.956, r^{2}=0.978\right.$ in three repeated tests; see Figure 3 and Table 2) although constants and slope differed between the three experiments (Table 2). The results show that algae cell counts are more closely related to $\mathrm{O}_{2}$ assimilation rate than to $\mathrm{O}_{2}$ evolution rate. Figure 2 suggests that the slope of $\mathrm{O}_{2}$ evolution at lower algae cell counts is steeper than at high cell concentration, which was observed in all the three repeats.

\section{Comparison with Warburg Manometer}

$\mathrm{O}_{2}$ assimilation rates in the soil samples from the field experiment were analyzed by both oxygen optical microsensors
TABLE 2 | Slope, constant, and regression statistics for $\mathrm{O}_{2}$ evolution and assimilation in three independent calibration tests with Chlorella vulgaris.

\begin{tabular}{lcrrc}
\hline Calibration & $\begin{array}{c}\text { Cell counts } \\
\text { million cells } / \mathbf{m L}\end{array}$ & Slope & Constant & $\boldsymbol{r}^{\mathbf{2}}$ \\
\hline $\mathrm{O}_{2}$ evolution rate & $0.5-260$ & 0.117 & 5.217 & 0.894 \\
$\mathrm{O}_{2}$ evolution rate & $2.5-270$ & 0.117 & 4.990 & 0.899 \\
$\mathrm{O}_{2}$ evolution rate & $0.6-260$ & 0.099 & 3.772 & 0.888 \\
\hline $\mathrm{O}_{2}$ assimilation rate & $0.5-250$ & -0.024 & -5.456 & 0.939 \\
$\mathrm{O}_{2}$ assimilation rate & $0.6-210$ & -0.025 & 0.071 & 0.956 \\
$\mathrm{O}_{2}$ assimilation rate & $0.5-250$ & -0.026 & -0.153 & 0.978
\end{tabular}

and traditional Warburg (Figure 4). No significant difference was observed between the results measured by these two methods (Table A3). Both methods showed that samples Control and sample $\mathrm{Kf}$ had the lowest $\mathrm{O}_{2}$ assimilation rates and did not differ significantly. Sample Wild with wild algae had the highest $\mathrm{O}_{2}$ assimilation rate and sample Mix with mixed culture of wild algae and laboratory cultured algae was intermediate (not significant in the group of microsensor, see Table A4). This indicates that the laboratory cultured filamentous algae $K$. flaccidium did not grow as well as the wild algae species in the field test.

\section{DISCUSSION}

The aim of this work was to develop a contact-free assessment of the relationship between algae cell counts (or concentrations) and cell activity (cell respiration rate and cell photosynthesis rate) using oxygen optical microsensors for future use in ecotoxicological studies. Oxygen optical microsensors have widely been used for measurements of oxygen assimilation in biogeochemistry or in sediments (Buffle and Horvai, 2000). Also when measuring communities of microalgae in situ oxygen microsensors rendered satisfying results (McMinn et al., 2000; Kühl et al., 2001). The results of oxygen evolution rate and assimilation rate in this study showed that algae cell counts could be better predicted by $\mathrm{O}_{2}$ assimilation rate. A large range of algae cell counts from 0.5 million cells $/ \mathrm{ml}$ to 260 million cells $/ \mathrm{ml}$ can be well-correlated with cell respiration rate. $\mathrm{O}_{2}$ evolution rate did not fit with as well a linear regression as $\mathrm{O}_{2}$ assimilation since the correlation coefficients $\left(r^{2}\right)$ between $C$. vulgaris cell counts and $\mathrm{O}_{2}$ evolution were always lower than that between $C$. vulgaris cell counts and assimilation rate. The oxygen evolution rate increased much faster at low than at high algae cell concentrations (Figure 2). Although several non-linear regressions (data not shown) revealed that fitting a cubic function rendered a higher $r^{2}$ this did not always increase the explained variance ( $F$ value). Moreover, Figure 2 rather suggests a two-phase system than a continuous function. Therefore (and in order to not unnecessarily complicate the calibration curve), we decided to stick to the linear model. There are four possible explanations for this: at high algae cell concentrations, (1) photosynthesis capacity declines due to the cell-shading effect (Baumert, 1996; Han et al., 2000), (2) carbon dioxide concentration decreases fast 


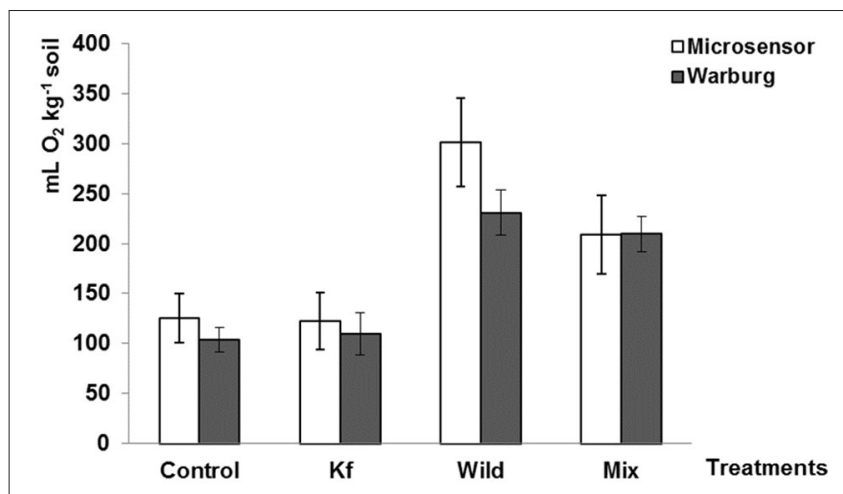

FIGURE 4 | $\mathrm{O}_{2}$ assimilation rate measured by oxygen optical microsensor (white) and Warburg (black) manometer (Mean, $n=12$, \pm SE). Control: pure ReviTec ${ }^{\circledR}$ soil, Kf: ReviTec ${ }^{\circledR}$ soil plus laboratory cultured filamentous algae $K$. flaccidium, Wild: ReviTec ${ }^{\circledR}$ soil plus wild algae population, Mix: ReviTec ${ }^{\circledR}$ soil plus mixed cultures of $K$. flaccidium and wild population. Warburg data was kindly provided by Thomas Buse.

(Fogg, 1985), (3) oxygen concentration increases, which inhibits the photosynthesis process (Han et al., 2000), and (4) autotoxicity due to allelochemicals released above a certain cell density (Pratt and Fong, 1940). Therefore, using $\mathrm{O}_{2}$ evolution rate to evaluate the algae cell counts is restrained by the cell concentrations.

Thus, $\mathrm{O}_{2}$ assimilation is chosen as predictor for algae cell counts based on cell respiration. The tests were conducted three times separately to test the repeatability of the calibration curve. All three $\mathrm{O}_{2}$ assimilation tests revealed significant correlation coefficients with $r^{2}$ never below 0.9 (Table 2). The different constants and slopes might be due to varying biotic and abiotic factors, e.g., the growth conditions of algae, air pressure, and oxygen saturation in the air. Therefore, although the performance of algae in three tests was slightly different, each of them was sufficient to predict cell counts on the basis of cell respiration rate using contact-free oxygen optical microsensors.

Compared with Warburg, the measurement of the experimental soil samples using the oxygen optical microsensor proved to be as sensitive and accurate as Warburg but more convenient and faster. Both methods detected the highest microbial biomass in the treatment of wild algae with sandy

\section{REFERENCES}

Ananyeva, N. D., Susyan, E. A., and Gavrilenko, E. G. (2011). Determination of the soil microbial biomass carbon using the method of substrate-induced respiration. Eurasian J. Soil Sci. 44, 1215-1221. doi: 10.1134/S1064229311030021

Anderson, J. P. E., and Domsch, K. H. (1978). Physiological method for quantitative measurement of microbial biomass in soils. Soil Biol. Biochem. 10, 215-221. doi: 10.1016/0038-0717(78)90099-8

Ast, C., Schmalzlin, E., Lohmannsroben, H. G., and van Dongen, J. T. (2012). Optical oxygen micro- and nanosensors for plant applications. Sensors 12, 7015-7032. doi: 10.3390/s120607015

Baumert, H. (1996). On the theory of photosynthesis and growth in phytoplankton. Part 1: light limitation and constant temperature. Int. Rev. Ges. Hydrobiol. 81, 109-139. doi: 10.1002/iroh.19960810113 soil and the lowest microbial biomass in pure sandy soil. The accuracy and efficiency of this microsensor method have been confirmed by preliminary results in long-term field study (Buse, unpublished data).

\section{CONCLUSIONS}

The developed method appears promising for application in ecotoxicological tests, which has been proven in our field experiment (Zhang, 2017). The fast and widely available oxygen optical microsensor is well-suited for contact-free oxygen assimilation rate measurements. Moreover, it is accurate and effective with adequate sensitivity for investigating soil microorganisms when compared with the traditional manometer (Warburg) method. It appears promising to apply this contactfree oxygen optical microsensor method to ecotoxicological tests in both aquatic and terrestrial systems.

\section{AUTHOR CONTRIBUTIONS}

The funding was secured by JF. XZ and JF designed the tests which were performed and analyzed by XZ. XZ analyzed the data of the chemical analyses. The manuscript was written and reviewed by $\mathrm{XZ}$ and JF.

\section{ACKNOWLEDGMENTS}

We would like to thank Russell Lodge and Yvonne Sakka for helpful criticism on the manuscript, and Prof. Hartmut Koehler and Birthe Schroeder for help with the experimental design. Special thanks go to Thomas Buse for providing unpublished data for the Warburg test, Moira McKee for correcting the English and Tong Wu for laboratory assistant work. The research work was financially supported by the UMSICHT project (BMBF 0340091A) and the Chinese Scholarship Council.

\section{SUPPLEMENTARY MATERIAL}

The Supplementary Material for this article can be found online at: https://www.frontiersin.org/articles/10.3389/fenvs. 2017.00091/full\#supplementary-material

Bowe, G. (2007). "An overview of counting methods of algae," in Water Quality Measurements Series, eds F. Palumbo, G. Ziglio, and A. van der Beken (John Wiley and Sons, Ltd), $71-82$.

Buffle, J., and Horvai, G. (2000). In Situ Monitoring of Aquatic Systems: Chemical Analysis and Speciation. Wiley.

Buse, T., Ruess, L., and Filser, J. (2013). New trophic biomarkers for Collembola reared on algal diets. Pedobiologia 56, 153-159. doi: 10.1016/j.pedobi.2013. 03.005

Castle, S. C., Morrison, C. D., and Barger, N. N. (2011). Extraction of chlorophyll a from biological soil crusts: a comparison of solvents for spectrophotometric determination. Soil Biol. Biochem. 43, 853-856. doi: 10.1016/j.soilbio.2010. 11.025

Drobnik, J. (1960). Warburg vessel for soil samples. Nature 188, 686-686. doi: $10.1038 / 188686 a 0$ 
Field, C. B., Behrenfeld, M. J., Randerson, J. T., and Falkowski, P. (1998). Primary production of the biosphere: integrating terrestrial and oceanic components. Science 281, 237-240. doi: 10.1126/science.281.53 74.237

Fogg, G. E. (1985). Algae as ecological indicators - Shubert, Le. J. Environ. Manage. $21,379-380$

Gansert, D., Burgdorf, M., and Losch, R. (2001). A novel approach to the in situ measurement of oxygen concentrations in the sapwood of woody plants. Plant Cell Environ. 24, 1055-1064. doi: 10.1046/j.1365-3040.2001.00751.x

Grote, M., Schuurmann, G., and Altenburger, R. (2005). Modeling photoinduced algal toxicity of polycyclic aromatic hydrocarbons. Environ. Sci. Technol. 39, 4141-4149. doi: 10.1021/es048310v

Han, B.-P., Virtanen, M., Koponen, J., and Straškraba, M. (2000). Effect of photoinhibition on algal photosynthesis: a dynamic model. J. Plankton Res. 22, 865-885. doi: $10.1093 /$ plankt/22.5.865

Hoffmann, L. (1989). Algae of terrestrial habitats. Bot. Rev. 55, 77-105. doi: $10.1007 / \mathrm{BF} 02858529$

Holst, G., Kuhl, M., and Klimant, I. (1995). A novel measuring system for oxygen microoptodes based on a phase modulation technique. Chem. Biochem. Environ. Fiber Sensors VII 2508, 387-398. doi: 10.1117/12.221754

Hynes, J., Hill, R., and Papkovsky, D. B. (2006). The use of a fluorescencebased oxygen uptake assay in the analysis of cytotoxicity. Toxicol. In Vitro 20, 785-792. doi: 10.1016/j.tiv.2005.11.002

Jeffrey, S. W. (1974). Profiles of photosynthetic pigments in the ocean using thin-layer chromatography. Mar. Biol. 26, 101-110. doi: 10.1007/BF00388879

Johansen, J. R. (1993). Cryptogamic crusts of semiarid and arid lands of NorthAmerica. J. Phycol. 29, 140-147. doi: 10.1111/j.0022-3646.1993.00140.x

Kaiser, E. A., Mueller, T., Joergensen, R. G., Insam, H., and Heinemeyer, O. (1992). Evaluation of methods to estimate the soil microbial biomass and the relationship with soil texture and organic-matter. Soil Biol. Biochem. 24, 675-683. doi: 10.1016/0038-0717(92)90046-Z

Kleinzeller, A. C. (1965). Manometrische Methoden und ihre Anwendung in der Biologie und Biochemie. Jena; Prag: VEB Gustav Fischer Verlag; Tschechoslowakischer Verlag für medizinische Literatur.

Klimant, I., Meyer, V., and Kuhl, M. (1995). Fiberoptic oxygen microsensors, a new tool in aquatic biology. Limnol. Oceanogr. 40, 1159-1165. doi: 10.4319/lo.1995.40.6.1159

Kohler, R. E. (1973). The background to Otto Warburg's conception of the Atmungsferment. J. Hist. Biol. 6, 171-192. doi: 10.1007/BF00127607

Kohra, S., Tominaga, N., Takao, Y., Nagae, M., Ishibashi, Y., Ueda, K., et al. (2002). A rapid respiratory toxicity test using Caenorhabditis elegans with an oxygen electrode system. J. Health Sci. 48, 269-272. doi: 10.1248/jhs.48.269

Krienitz, L. (2009). "Algae," in Encyclopedia of Inland Waters, eds G. E. Likens, M. Eric Benbow, T. M. Burton, E. van Donk, J. A. Downing, R. D. Gulati, D. O. Hessen, G. Hornberger, R. W. Howarth, J. R. Jones, T. Kratz, W. Lampert, W. M. Lewis, A. Lorke, S. MacIntyre, R. Merritt, M. Meybeck, M. Pace, J. Padisák, M. Søndergaard, K. M. Stewart, F. B. Taub, I. J. Winfield, and T. C. Winter (Oxford: Academic Press), 103-113.

Kühl, M. (2005). Optical microsensors for analysis of microbial communities. Environ. Microbiol. 397, 166-199. doi: 10.1016/S0076-6879(05)97010-9

Kühl, M., Glud, R., and Borum, J. (2001). Photosynthetic performance of surfaceassociated algae below sea ice as measured with a pulse-amplitude-modulated (PAM) fluorometer and O2 microsensors. Mar. Ecol. Prog. Ser. 223, 1-14. doi: 10.3354/meps223001

Lan, S. B., Wu, L., Zhang, D. L., Hu, C. X., and Liu, Y. D. (2011). Ethanol outperforms multiple solvents in the extraction of chlorophyll-a from biological soil crusts. Soil Biol. Biochem. 43, 857-861. doi: 10.1016/j.soilbio.2010.12.007

Matzke, M., Stolte, S., Boschen, A., and Filser, J. (2008). Mixture effects and predictability of combination effects of imidazolium based ionic liquids as well as imidazolium based ionic liquids and cadmium on terrestrial plants (Triticum aestivum) and limnic green algae (Scenedesmus vacuolatus). Green Chem. 10, 784-792. doi: 10.1039/b802350f

McMinn, A., Ashworth, C., and Ryan, K. G. (2000). In situ net primary productivity of an Antarctic fast ice bottom algal community. Aquat. Microb. Ecol. 21, 177-185. doi: 10.3354/ame021177

Nyholm, N. (1990). Expression of results from growth-inhibition toxicity tests with algae. Arch. Environ. Contam. Toxicol. 19, 518-522. doi: 10.1007/BF01059070
Nyholm, N., and Damgaard, B. M. (1990). A comparison of the algal growthinhibition toxicity test method with the short-term C-14 assimilation test. Chemosphere 21, 671-679. doi: 10.1016/0045-6535(90)90034-Q

O'Mahony, F. C., and Papkovsky, D. B. (2006). Rapid high-throughput assessment of aerobic bacteria in complex samples by fluorescencebased oxygen respirometry. Appl. Environ. Microbiol. 72, 1279-1287. doi: 10.1128/AEM.72.2.1279-1287.2006

O'Riordan, T. C., Buckley, D., Ogurtsov, V., O'Connor, R., and Papkovsky, D. B. (2000). A cell viability assay based on monitoring respiration by optical oxygen sensing. Anal. Biochem. 278, 221-227. doi: 10.1006/abio.1999.4431

Porter, K. G., Gerritsen, J., and Orcutt, J. D. (1982). The effect of food concentration on swimming patterns, feeding-behavior, ingestion, assimilation, and respiration by daphnia. Limnol. Oceanogr. 27, 935-949. doi: 10.4319/lo.1982.27.5.0935

Pratt, R., and Fong, J. (1940). Studies on Chlorella vulgaris II. Further evidence that Chlorella cells form a growth-inhibiting substance. Am. J. Bot. 431-436. doi: $10.2307 / 2436459$

Revsbech, N. P. (1989). Diffusion characteristics of microbial communities determined by use of oxygen microsensors. J. Microbiol. Methods 9, 111-122. doi: 10.1016/0167-7012(89)90061-4

Schaefer, M., Petersen, S. O., and Filser, J. (2005). Effects of Lumbricus terrestris, Allolobophora chlorotica and Eisenia fetida on microbial community dynamics in oil-contaminated soil. Soil Biol. Biochem. 37, 2065-2076. doi: 10.1016/j.soilbio.2005.03.010

Schmidt, O., Dyckmans, J., and Schrader, S. (2016). Photoautotrophic microorganisms as a carbon source for temperate soil invertebrates. Biol. Lett. 12:20150646. doi: 10.1098/rsbl.2015.0646

Simon, D., Helliwell, S., and Robards, K. (1997). Pesticide toxicity endpoints in aquatic ecosystems. J. Aquat. Ecosyst. Stress Recov. 6, 159-177. doi: 10.1023/A:1009920227241

Sparling, G. P., Ord, B. G., and Vaughan, D. (1981). Microbial biomass and activity in soils amended with glucose. Soil Biol. Biochem. 13, 99-104. doi: 10.1016/0038-0717(81)90003-1

Sweerts, J. P. R. A., Debeer, D., Nielsen, L. P., Verdouw, H., Vandenheuvel, J. C., Cohen, Y., et al. (1990). Denitrification by sulfur oxidizing beggiatoa spp mats on fresh-water sediments. Nature 344, 762-763. doi: 10.1038/344762a0

Syrett, P. J. (1951). The effect of cyanide on the respiration and the oxidative assimilation of glucose by Chlorella-vulgaris. Ann. Bot. 15, 473-492. doi: 10.1093/oxfordjournals.aob.a083293

Tchan, Y. T. (1952). Counting soil algae by direct fluorescence microscopy. Nature 170, 328-329. doi: 10.1038/170328b0

Tsujimura, S., Nakahara, H., and Ishida, N. (2000). Estimation of soil algal biomass in salinized irrigation land: a comparison of culture dilution and chlorophyll a extraction methods. J. Appl. Phycol. 12, 1-8. doi: 10.1023/A:1008126 232188

Warburg, O. (1956). On the origin of cancer cells. Science 123, 309-314. doi: $10.1126 /$ science.123.3191.309

Warkentin, M., Freese, H. M., Karsten, U., and Schumann, R. (2007). New and fast method to quantify respiration rates of bacterial and plankton communities in freshwater ecosystems by using optical oxygen sensor spots. Appl. Environ. Microbiol. 73, 6722-6729. doi: 10.1128/AEM.00405-07

Wetzel, M. A., Jensen, P., and Giere, O. (1995). Oxygen/sulfide rexime and nematode fauna associated with Arenicola marina burrows: new insights in the thiobios case. Mar. Biol. 124, 301-312. doi: 10.1007/BF00347134

Zhang, X. (2017). Ecotoxicological Effects of Silver Nanoparticles: The Relevance of Test Species and Test Conditions. Dissertation, University of Bremen.

Conflict of Interest Statement: The authors declare that the research was conducted in the absence of any commercial or financial relationships that could be construed as a potential conflict of interest.

Copyright (C) 2017 Zhang and Filser. This is an open-access article distributed under the terms of the Creative Commons Attribution License (CC BY). The use, distribution or reproduction in other forums is permitted, provided the original author(s) or licensor are credited and that the original publication in this journal is cited, in accordance with accepted academic practice. No use, distribution or reproduction is permitted which does not comply with these terms. 